\title{
Self-mutilation in the Lesch-Nyhan syndrome
}

\section{Boby Varkey Maramattom, MD, DM}

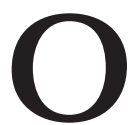

ver the last few years, this 12-year-old boy had chewed off his lips and tongue, bitten his left arm, and eroded his nose by rubbing it on the floor (figures 1 and 2). He was bed bound and dependent for activities of daily living. CT head was normal. His serum uric acid level was $11.5 \mathrm{mg}$, and ultrasound of the abdomen showed multiple renal calculi. Nerve conduction studies were normal.

The Lesch-Nyhan syndrome results from deficient hypoxanthine-guanine phosphoribosyltransferase activity. Clinical features include hyperuricemia, developmental delay, movement disorders, and self-mutilation targeted to the lips, tongue, and digits. ${ }^{1}$ The differential diagnosis includes congenital insensitivity to pain.

\section{Reference}

1. Lesch M, Nyhan WL. A familial disorder of uric acid metabolism and central nervous system function. Am J Med 1964;36:561-570.

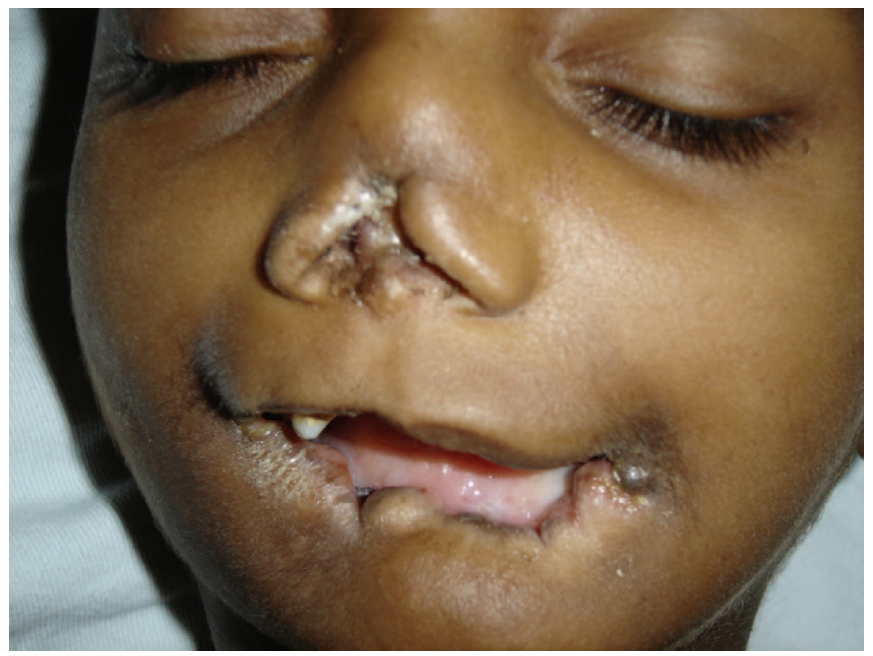

Figure 1. Mutilation of the lips, tongue and nose.

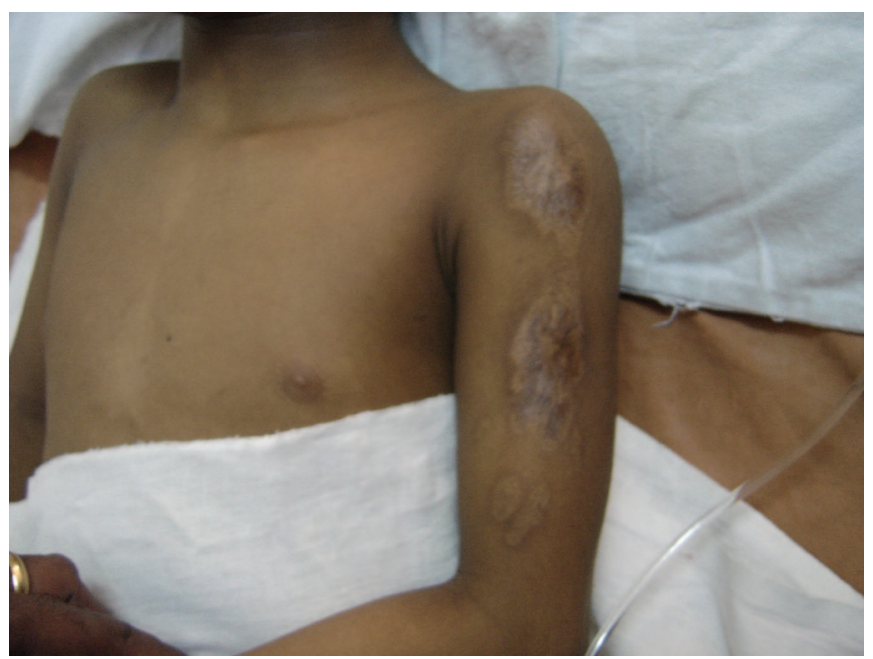

Figure 2. Healed scars on his left arm following self-biting. 


\title{
Neurology
}

\author{
Self-mutilation in the Lesch-Nyhan syndrome \\ Boby Varkey Maramattom \\ Neurology 2005;65;E25 \\ DOI 10.1212/01.wnl.0000184611.55051.f3
}

This information is current as of December 12, 2005

\section{Updated Information \&} Services

\section{References}

Subspecialty Collections

Permissions \& Licensing

Reprints including high resolution figures, can be found at: http://n.neurology.org/content/65/11/E25.full

This article cites 1 articles, 0 of which you can access for free at: http://n.neurology.org/content/65/11/E25.full\#ref-list-1

This article, along with others on similar topics, appears in the following collection(s):

Metabolic disease (inherited)

http://n.neurology.org/cgi/collection/metabolic_disease_inherited

Information about reproducing this article in parts (figures,tables) or in its entirety can be found online at:

http://www.neurology.org/about/about_the_journal\#permissions

Information about ordering reprints can be found online:

http://n.neurology.org/subscribers/advertise

Neurology ${ }^{\circledR}$ is the official journal of the American Academy of Neurology. Published continuously since 1951, it is now a weekly with 48 issues per year. Copyright. All rights reserved. Print ISSN: 0028-3878. Online ISSN: 1526-632X.

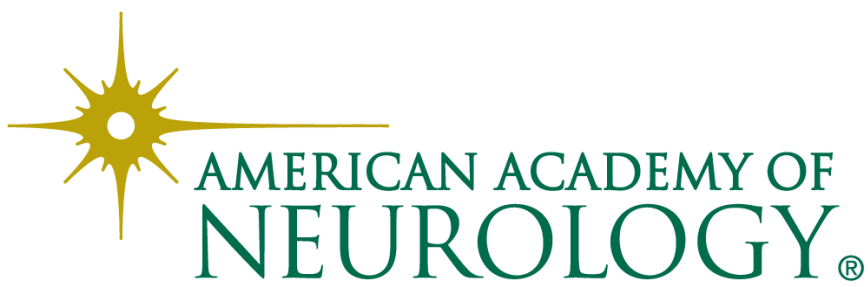

